\title{
EDITORIAL
}

\section{Sobre educar e transgredir}

\author{
Marília Freitas de Campos Tozoni-Reis ${ }^{1}$ \\ https://orcid.org/0000-0001-8726-8015
}

O amadurecimento do campo da educação ambiental no Brasil, notadamente nos estudos e pesquisa em educação ambiental, é muito bom para todos nós e traz, por isso e com isso, muitos desafios. No âmbito da educação ambiental crítica, ou seja, aquela que olha, pensa e faz o ambiente considerando-o não somente natural, mas histórico, cultural, social e político, e, portanto, essencialmente contraditório, nossos desafios estão voltados para responder às necessidades ambientais nessa perspectiva crítica. Nunca isso foi tão urgente e necessário como nesses tempos atuais obscuros - social e politicamente - em vários países do mundo. No Brasil, especialmente neste ano de 2019, isso está muito evidente, principalmente ao assumir o poder um governo que, como já anunciava em campanha, entre muitas outras perversidades pretende aprofundar a secundarização da proteção ambiental que já assistimos desde que essa proteção esteve em pauta no mundo. Esse aprofundamento chegou ao limite de propor a própria extinção do Ministério do Meio Ambiente que deveria diluir-se no Ministério da Agricultura, cuja orientação hegemônica é dada pelo Agronegócio: para nós nada mais assustador! A proposta foi, então, rejeitada pelo próprio setor agrícola - do Agronegócio -, e por isso foi abandonada ou pelo menos reformulada. Mas, a ideia em si é um importante indicador das posições e intenções que devem balizar, durante todo o mandato que agora se inicia, das políticas ambientais no Brasil, ou seja, obstáculos gigantes e perspectivas sombrias nos assolam.

Ao mesmo tempo em que vivemos o aprofundamento da "desproteção" ambiental, tivemos, também, neste conturbado início de ano, uma das mais perversas e anunciadas tragédias socioambientais de nossa história: o rompimento da barragem da Mineradora Vale - que simbolicamente não é mais "do Rio Doce" - em Brumadinho, MG, depois de menos de três anos da também tragédia de Mariana, MG, que, além de anunciada já anunciava o sombrio 25 de janeiro de 2019. Sabemos que muitas outras estão por vir. Tragédias anunciadas não são acidentes, são crimes, crimes dolosos, quando há intenção de matar: matar pessoas, matar animais, matar matas, matar rios, matar sonhos e esperanças de vivermos e convivermos não harmoniosa, mas decente e equilibradamente no mundo social e natural, de construirmos relações dos seres humanos entre si e deles com a natureza, que valorize a vida, o belo e o bom.

\footnotetext{
${ }^{1}$ Universidade Estadual Paulista (UNESP), Faculdade de Ciências, Programa de Pós-graduação em Educação para a Ciência, Bauru, SP, Brasil. E-mail: mariliatozoni@uol.com.br.
} 
É neste contexto socioambiental, histórico, cultural, político, econômico e social, que continuamos a lutar pela construção de uma educação ambiental, seja no âmbito escolar ou no âmbito social mais amplo, isto é, fora da escola.

A produção de conhecimentos em educação ambiental, assim como as ações educativas que ela objetiva contribuir, em sua abordagem radicalmente crítica como a que defendemos, exigem, de forma ainda mais premente, enfrentarmos o vandalismo econômico do modo de produção capitalista que atinge todas as dimensões de nossa vida, nos sufocando e oprimindo com todos os seus tentáculos. Esse imenso mar de lama de rejeitos de humanos e de natureza resultante da produção do capital, que nos oprime e sufoca, nos mostra contraditoriamente que é hora de transgredir. Transgredir na produção de conhecimentos, transgredir com e para além do conhecimento que já temos, problematizando saberes, "cutucando-os", desafiando-os a responder nossas novas - e também permanentes - inquietações e necessidades. E, transgredir quando a lógica é competir, é cooperar. Transgredir quando a lógica é reproduzir, é criar e recriar. Transgredir para sentir e pensar. Transgredir é educar para pensar, educar para compartilhar, para cooperar, para compreender o que nos faz iguais e diferentes, o que nos oprime e o que nos empodera, o que produz reproduzindo e o que produz transformando. Transgredir para empoderar, libertar, para amar e para viver. Transgredir para educar e educar para transgredir.

Assim, a educação ambiental somente educa se for transgressora e se for para transgredir. Se na escola a educação ambiental vem para dominar e para "adestrar", transgredir é acreditar que os saberes ambientais a serem apropriados, serão transformadores se construídos coletiva e cooperativamente, democrática e participativamente, saberes compartilhados, compartidos e "com partido": saberes sobre a realidade concreta, resultado da leitura corajosa do mundo, daquilo que nos leva a um processo de aproximação crítica da realidade vivida, da consciência da opressão e da necessidade da ação.

Assim, somente a coragem para transgredir na educação, na pesquisa, na escola e no ensino, pode fazer sentido para a educação e para a educação ambiental crítica e transformadora, para a educação ambiental que queremos ver instrumentalizando criticamente os alunos da escola para construírem novas barragens que acumulem forças individuais e sociais mais fortalecidas para o enfrentamento daquilo que o modo de produção capitalista sabe fazer com a maior competência: a opressão de gentes e ambientes.

\section{Referências}

BRANDÃO, C. R. O ambiente, o sentimento e o pensamento: dez esboços de ideias para pensar o trabalho do ambientalista e do educador ambiental. In: DICKMANN, I.; BATTESTIN, C. (org.). Educação ambiental na América Latina. Chapecó: Plataforma Acadêmica, 2018. p. 7-43.

TREIN, E. S. Educação ambiental crítica: crítica de quê? Revista Contemporânea de Educação, Rio de janeiro, v. 7, n. 14, p. 295-308, 2012. Disponível em: https://revistas.ufrj. br/index.php/rce/article/view/1673/1522. Acesso em: 27 fev. 2019.

TOZONI-REIS, M. F. C. Prefácio: transgredindo e reinventando. In: DICKMANN, I.; BATTESTIN, C. (org.). Educação ambiental na América Latina. Chapecó: Plataforma Acadêmica, 2018. p. 4-6. 